\title{
RELASI DAN MOTIVASI ANTAR TOKOH DALAM NOVEL SAMAN KARYA AYU UTAMI
}

\author{
Siti Sumarsilah \\ sumarsilah1957@gmail.com
}

\begin{abstract}
Abstrak
Tokoh merupakan salah satu unsur pembangun dalam novel. Tokoh menjadi bagian penting karena dari tokoh pembaca dapat memahami apa yang ingin disampaikan penulis. Novel Saman Karya Ayu Utami menceritakan tentang pergolakkan yang terjadi pada tokoh-tokohnya yang hidup pada tahun itu. Tokoh dalam Novel Saman memiliki relasi dan motivasi satu sama lain. Relasi diperlukan untuk menjaga eksistensi hubungan manusia dengan manusia yang lain. Hal itu disebabkan oleh refleksi atas eksistensi manusia sebagai pribadi. Penelitian ini menggunakan pendekatan sosiologi sastra. Hasil penelitian menunjukkan bahwa relasi antara Laila dengan Sihar tidak menjadi relasi dalam kata "Kita". Sebab tidak ada kebersamaan antara Laila dan Sihar. Relasi antara Wisanggeni (Saman) dengan Yasmin merupakan relasi yang didasari oleh cinta, sehingga hubungan itu berada dalam relasi "Kita" atau pertemuan yang sebenarnya. Relasi antara Wisanggeni (Saman) dengan Upi, Anson, Mak Argani, dan petani karet di kampung Sei Kumbang merupakan hubungan etis, hubungan kewajiban. Hubungan itu dimulai dari hubungan sosial yang saling mengakui masing-masing sebagai subjek dan cita-cita mereka dalam kebersamaan. Hasil penelitian ini dapat digunakan untuk mengajarkan apresiasi sastra dalam upaya menggali nilai-nilai dalam karya sastra dan bersikap kritis untuk memberikan tanggapan dan mengambil manfaat nilai-nilai dari karya sastra yang dibaca.
\end{abstract}

Kata kunci: relasi, motivasi, tokoh, novel

\section{RELATION OF MOTIVATION BETWEEN FIGURES IN THE SAMAN NOVEL BY AYU UTAMI}

\begin{abstract}
Figure is a building element in the novel. Figure becomes an important part because the reader can understand what the writer wants to convey. The Saman novels by Ayu Utami tells about the upheaval that happened to her characters who lived that year. People in the Saman novels have relationships and motivations with each other. Relations are needed to maintain the existence of human
\end{abstract}


relations with other humans. This is due to reflection on human existence as a person. This study uses the sociology of literature approach. The results showed that the relationship between Laila and Sihar did not become a relation in the word "We". Because there is no togetherness between Laila and Sihar. The relation between Wisanggeni (Saman) and Yasmin is a relationship based on love, so that the relationship is in the "We" relationship or the actual meeting. The relation between Wisanggeni (Saman) and Upi, Anson, Mak Argani, and rubber farmers in the village of Sei Kumbang is an ethical relationship, an obligation relationship. The relationship starts from social relationships that mutually recognize each other as their subjects and ideals in togetherness. The results of this study can be used to teach literary appreciation in an effort to explore values in literary works and be critical to provide responses and take advantage of the values of literary works that are read.

Keywords: relation, motivation, character, novel

\section{PENDAHULUAN}

Karya sastra merupakan bagian dari seni yang menggunakan bahasa sebagai medianya. Karya sastra memiliki tiga genre, yaitu puisi, prosa, dan drama. Prosa dalam genre sastra terdiri atas cerpen dan novel. Karya sastra merupakan wujud dari ekspresi penulisnya untuk menuangkan segala ide, perasaan, imajinasinya. Faruk (2012:25) menyatakan bahwa sastra merupakan objek yang manusiawi, fakta kemanusiaan yang dapat dikaji lebih lanjut. Melalui karya sastra pengarang dapat dengan bebas berbicara tentang kehidupan yang dialami oleh manusia dengan berbagai peraturan dan norma-norma dalam interaksinya dengan lingkungan sehingga dalam karya sastra terdapat makna tertentu tentang kehidupan. Karya sastra merupakan sebuah struktur yang sangat komplek. Karya sastra juga memiliki hubungan dengan kehidupan, sastra merupakan ekspresi kehidupan manusia yang tidak terlepas dari akar masyarakatnya. Kehidupan yang dituangkan dalam karya sastra mencakup hubungan manusia dengan lingkungan dan masyarakat, hubungan sesama manusia, hubungan manusia dengan dirinya, 
dan hubungan manusia dengan Tuhan.

Menurut Nurgiyantoro (2010: 3) karya sastra merupakan karya imajinatif yang digunakan pengarang dalam bentuk tulisan yang mempunyai estetika. Karya imajinatif tersebut terlahir dari kreasi dan daya khayal pengarang. Sastra tidak akan semata-mata menyodorkan fakta secara mentah. Sastra bukan sekedar tiruan kenyataan, melainkan kenyataan yang telah ditafsirkan oleh pengarang dari kehidupan yang ada disekitarnya. Karya sastra merupakan penjabaran dan pengalaman pengarang atas kehidupan disekitarnya.

Novel merupakan salah satu karya sastra yang banyak diminati oleh masyarakat. Novel Menurut Kosasih (2003:250) adalah karya imajinatif yang bercerita tentang sisi utuh atas problematika kehidupan seseorang atau beberapa orang tokoh. Maksudnya jelas bahwa novel merupakan sebuah karya cipta manusia yang diwujudkan oleh seorang penulis melalui penggambaran berbagai kisah hidup yang dialami seseorang dengan untaian kisah, baik suka maupun duka yang muncul dalam kehidupan sang tokoh yang diceritakan dalam karya fiksi berbentuk novel.

Novel Saman merupakan salah satu novel karya Ayu Utami yang memenangkan Sayembara Roman Dewan Kesenian Jakarta pada tahun 1998. Novel Saman menceritakan tentang pergolakkan yang terjadi pada tokoh-tokohnya yang hidup pada tahun itu. Tokoh-tokoh dalam Novel Saman karya Ayu Utami memiliki relasi satu sama lain. Relasi diperlukan untuk menjaga eksistensi hubungan manusia denagn manusia yang lain. Hal itu disebabkan oleh refleksi atas eksistensi manusia sebagai pribadi yang menurut Leenhouwers (1968:63) merupakan tujuan para filosof dalam bersilfasat.

Tokoh-tokoh yang terdapat dalam Novel Saman karya Ayu Utami memiliki motivasi yang berbeda-beda dalam menjalin relasi dengan tokoh lain. Selain itu, karakter tokoh-tokoh dalam Novel Saman sangat kuat. Loncatan cerita yang dikisahkan dengan teknik asosiasi, montase dan kolase itu dapat dirakit kembali oleh pembaca dengan memahami relasi dan 
karakter tokoh. Gambaran karakter para tokoh yang diciptakan Ayu Utami dalam Novel Saman merupakan gambaran individu yang mempunyai relasi dalam menciptakan eksistensi dan bersifat unik.

Rumusan masalah yang dikaji dalam penelitian ini sebagai berikut, bagaimanakah relasi dan motivasi antara Laila dengan Sihar, antara Wisanggeni (Saman) dengan Yasmin, dan antara Wisanggeni dengan Upi, Angson, dan para petani di Sei Kumbang?. Sesuai dengan rumusan masalah, maka tujuan penelitian ini untuk mendeskripsikan relasi dan motivasi antara Laila dengan Sihar, antara Wisanggeni (Saman) dengan Yasmin, dan antara Wisanggeni dengan Upi, Angson, dan para petani di Sei Kumbang.

\section{METODE PENELITIAN}

Penelitian ini merupakan penelitian kualitatif. Pendekatan yang digunakan, yaitu pendekatan sosiologi sastra. Pendekatan sosiologi sastra menurut Endraswara (2008: 87-88) merupakan pendekatan penelitian tentang (a) studi ilmiah manusia dan masyarakat secara objektif, (b) studi lembaga-lembaga sosial, (c) studi proses sosial, yaitu bagaimana masyarakat bekerja dan bagaimana masyarakat dalam melangsungkan kehidupannya.

Data yang digunakan dalam penelitian ini merupakan data kualitatif, yaitu berupa kutipankutipan yang menganbarkan relasi dan motivasi yang terjadi antara tokoh-tokoh dalam Novel Saman Karya Ayu Utami. Data penelitian ini bersifat hermeneutis dan fenomenologis, artinya fenomenafenomena yang terdapat dalam data penelitian tidak disikapi sebagai realitas sebagaimana adanya tetapi ditafsirkan melalui hakikat yang mendasari fenomena tersebut.

Sumber data penelitian ini, yaitu Novel Saman Karya Ayu Utami yang diterbitkan oleh KPG (Kepustakaan Populer Gramedia) bekerja sama dengan Jurnal Kebudayaan Kalam Jakarta tahun 2006 . Novel yang digunakan merupakan novel cetakan ke-25 bulan Januari 2006 dengan jumlah halaman 195.

Analisis Data dalam penelitian ini meliputi beberapa langkah sebagai berikut (1) pembacaan secara kritis-kreatif terhadap data, (2) reduksi fenomenologis terhadap 
sumber data, (3) penyajian data yang terdiri atas identifikasi dan klasifikasi data berdasarkan domain masalah, (4) penafsiran fenomenologis terhadap data, dan (5) penyimpulan data. Dengan demikian diharapkan dapat diketahui gambaran relasi intersubjektivitas / hubungan dasar antar tokoh yang dipresentasikan dalam wacana novel Saman Karya Ayu Utami.

\section{HASIL DAN PEMBAHASAN}

\section{Relasi dan Motivasi Antara Laila dengan Sihar}

Sihar Situmorang dan Laila bertemu dalam sebuah kegiatan. Pertemuan yang singkat itu menimbulkan relasi antar keduanya. Hal ini dapat dilihat pada kutipan 1 berikut.

\section{Kutipan 1}

Ketika kami meninggalkan tempat itu, saya melihat si lelaki berkacamata itu mencopot singletnya, dan memakainya untuk melap keringat. Mula-mula di leher lalu di ketiak, dan dadanya yang telanjang.

Ia menatap saya. Kali ini ia menoleh ke mata saya yang duduk di samping Rosano. Meski hanya sebuah kontak psikhis yang singkat. Seperti orang malu-malu, seperti orang sombong, seperti cowok cuek ia beralih ke baki saya dan menyapa "Makanya sedikit sekali" Sihar
Situmorang. Dia tersenyum. (Saman, 2006:11)

Berdasarkan kutipan 1 diatas dijelaskan bahwa relasi ini menurut Marcel bukan didasari oleh pertemuan yang sebenarnya, meskipun diawali oleh suatu kehadiran, karena relasi itu didorong oleh kebutuhan biologis dan psikologis. Laila tergoda oleh sosok Sihar yang menyebabkan Laila rela menyerahkan jiwa raganya kepada Sihar.

Relasi antara Laila dan Sihar tersebut menurut Sartre, terjadi dengan kepura-puraan. Sihar purapura mencintai Laila, sehingga Laila berada dalam kerugian. Laila bersikap patologis, yaitu menyerahkan diri sepenuhnya sebagai objek sebagai Sihar. Hal ini dapat dilihat pada kutipan 2 berikut.

Kutipan 2

Lalu kami berbaring di ranjang, yang tudungnya pun belum disibakkan, sebab kami memang tak hendak tidur siang. Dia katakana dada saya besar, saya jawab tidak sepatah kata. Dia katakana apakah saya siap. Saya jawab tolong, saya masih perawan. (Adakah cara lain). Dia katakana, bibir saya indah. Ciumlah, cium di sini. Saya menjawab tanpa katakata. Tapi saya telah berdosa. Meskipun masih perawan. Perjalanan pulang dia bilang, sebaiknya kita tidak usah 
berkencang (saya tidak

menyangka) (Saman, 2006:4).

Berdasarkan kutipan 2 dapat dijelaskan bahwa dalam pertemuan selanjutnya, Laila yang sebelumnya menganggap laki-laki sebagai musuh utama telah menjadi kehilangan kepribadian (“Akunya”). Laila merelakan diri sepenuhnya untuk dijadikan objek bagi Sihar. Sebaliknya Sihar bersikap masokhisme, yaitu cenderung menjadikan Laila sebagai objek. Kehadiran Sihar dalam kehidupan Laila, bukankah pertemuan "AkuEngkau" sebagai relasi "Kita" yang sama-sama mengakui dan menerima sebagai subjek, tetapi merupakan penderitaan bagi Laila, semakin Laila masuk dalam relasi itu, semakin kehilangan kepribadian. Sebaliknya Sihar hanya berpura-pura sebagai objek Laila, padahal sebenarnya Sihar yang menjadikan Laila sebagai objek keinginannya. Dalam hal ini justru Sihar yang menempatkan sebagai fokus yang mengendalikan relasi.

Konflik lain timbul karena muncul pihak ketiga, yaitu Rosano. Sihar tidak menyukai Rosano karena Rosano terlibat dalam tewasnya sahabat Sihar. Laila yang memiliki relasi denagn Sihar ikut tidak suka dengan Rosaro dan berusaha membantu Sihar untuk membawa kasus ini ke jalur hukum. Hal ini dapat dilihat pada kutipan 3 dan 4 berikut.

Kutipan 3

"Kesukaannya pada Sihar menambah rasa sebalnya pada Rosano, dan ia mengingat mulut Rosano yang congkak sebagai moncong yang dipotret dengan lensa bulat sehingga orang bisa melihat kerongkongan dan katakata busuk di dalamnya (Saman, 2006:18).

\section{Kutipan 4}

"Apa salahnya usul saya dicoba? Saya punya teman pengacara. Dia pasti mau bantu. Paling tidak kalau kita mau bikin tekanan, Texcoil harus mengeluarkan uang lebih banyak untuk membungkam orangorang. Itu membuat dosa Rosano pada Texcoil lebih besar. Kalau dia tidak masuk penjara, sedikitnya dia harus dipecat..." Dan Laila merasa lega ketika ditangkapnya Sihar tertarik pada usulannya. Sihar nampak ingin mengeksplorasi ide yang dilontarkan Laila" (Saman, 2006: 21-22).

Berdasarkan kutipan 3 dan 4 diatas dapat dijelaskan bahwa Laila dan Sihar memiliki relasi akibat adanaya konflik dengan Rosano. hubungan Laila dan Sihar benarbenar dapat dipertemukan menjadi 
satu atau menjadi "Relasi Kita". Sihar dan Laila sebagai subjek yang bersatu melawan Rosano. Laila ingin Sihar melaporkan Rosano ke polisi. Tetapi Sihar menolak karena Rosano merupakan anak pejabat. Laila menawarkan bantuannya karena dia memiliki teman pengacara. Sihar pun akhirnay menyetujui tawaran Laila.

Relasi yang terjadi antara Laila dan Sihar menunjukkan perubahan relasi. Sihar tidak lagi menganggap Laila sebagai objek tetapi sebagai subyek yang memiliki pikiran. Mereka memiliki motivasi yang sama, yaitu untuk melaporkan Rosano ke polisi.

\section{Relasi dan Motivasi Antara Wisanggeni (Saman) dengan Yasmin}

Wisangeni (Saman) memiliki relasi dengan Yasmin. Relasi antara Saman dan Yasmin merupakan pertemuan "Aku-Engkau", yang didasari oleh cinta. Hal ini dapat dilihat pada kutipan 1

"Yasmin, surat ini ditulis dan dikirim dari Apartemen Sidney. $\mathrm{Aku}$ masih menumpang dia. Sekarang aku punya laptop dengan modem dan program internet. Kawan-kawan memberikannya agar aku bisa mengirim faks. Tapi aku juga memakainya untuk menulis catatan harian. Ini merupakan kebiasaan baru. Aku tak pernah menulis diary sebelumnya. Catatan tentang hidup rasanya terlalu romantis dan sentimentil. Tapi begitulah perasaanku saat ini. Aku kesepian" (Saman, 2006: 171).

Berdasarkan kutipan 1 diatas dapat dijelaskan bahwa terjadi pertemuan "Aku-Engkau" menjadi "Kita". Menurut Marcel suatu pertemuan yang saling membuka hati secara jujur dengan gerak dan kata merupakan pertemuan "AkuEngkau". Mereka rela melepaskan pikiran-pikiran egoistis dan bersedia untuk saling mendengarkan. Pertemuan itu terjadi atas dasar cinta Kutipan 2

"Saman, Thank God !Aku lega kamu selamat. Kamu enggak tahu, ya bagaimaan aku cemas dua minggu ini. Sejak kita berpisah di Pekanbaru, tak ada kabar lagi tentang kamu. Kamu seperti lenyap. Bahkan temanteman yang menjemput kamu juga tidak bisa ku hubungi. Aku khawatir jika kamu tertangkap atau kapalmu tenggelam”. (Saman, 2006: 171).

Kutipan 2 diatas menjelaskan relasi yang terjadi antara Saman dan Yasmin membuat mereka memiliki motivasi untuk saling memberi kabar. Yasmin sangat khawatir atas kondisi Saman. Hal ini karena kondisi keamanan yang terjadi di 
Pekanbaru dan membuat mereka berpisah.

\section{Kutipan 3}

"Saman, kalau kamu memang menulis diary, mau enggak kamu share dengan aku. I miss you. I really do. Aku ketemu beberapa teman dari Prabumulih. Mereka juga kehilangan kamu. Aku mengerti jika mereka menyayangi kamu. Kami semua sayang kamu.". "Yasmin, bagaimana aku bisa melupakan kamu. Tentu saja kamu boleh membaca catatan harianku" (Saman, 2006: 172 - 173).

\section{Kutipan 4}

"Saman, Forgive me, Please. Aku tidak tahu bagaimaan harus meminta maaf, sampai sampai dua hari ini aku tidak berani membalas suratmu. Aku menyesal sekali. Apakah kamu menganggap Hawa yang menggoda Adam ?"

"Yasmin, tahukah kamu bahwa kisah itu telah menginspirasikan keputusan yang tidak adil bagi perempuan selama berabad-abad ? Tapi ya, kamu memang menggoda.

"Saman, apakah aku berdosa"

"Yasmin, aku tidak tahu lagi apakah masih ada dosa. Aku mencintai kamu. Aku mencintaimu. Aku tidak ingin kamu dihukum. (Saman, 2006: 183).

\section{Kutipan 5}

"Saman, kenapa keturunan begitu berarti bagi orang Israel ? Aku belum hamil juga. Bolehkah kami membuat bayi tabung ?

"Yasmin, aku pinya dua jawaban, yang nakal dan yang tida. Yang nakal : bolehkah aku mencoba menghamili kamu ? Yang tidak :
Gereja Katolik masih melarang bayi tabung"

"Saman kalau aku boleh jujur, aku menginginkan yang pertama. $\mathrm{Aku}$ menginginkan bayi dari tabunganmu. Berdosa tidak ya aku?"

"Yasmin, aku memang bimbang tentang Tuhan. Kamu selalu bicara tentang dosa. Tentu saja kita berdosa. Setidaknya pada Lukas (Saman, 2006: 190).

Berdasarkan kutipan 3, 4, dan 5 diatas, dapat diketahui bahwa kontak antara Saman dan Yasmin dilakukan dengan saling membuka hati secara jujur. Adanya seruan hati dari Yasmin dan adanya kesediaan hati dari Saman dengan hati yang terbuka dan jujur menimbulkan cinta sebagai dasar hubungan mereka. Cinta yang saling terbuka yang mau mengakui pasangannya sebagai subjek yang memiliki pikiran, perasaan dan citacita. Cinta yang mendasari hubungan itu timbul dan berkembang dan mencakup seluruh eksistensi Saman dan Yasmin sebagai manusia.

\section{Relasi Antara Wisanggeni (Saman) dengan Upi, Anson, dan Para Petani di Sei Kumbang}

Relasi yang terjadi antara Saman dengan Upi, Anson, dan para petani di Sei Kumbang didasari karena kasih sayang yang muncul 
karena hubungan sosial yang terjadi

di masyarakat.

\section{Kutipan 1}

"Wis pun tercenung. Dia menatap perempuan muda dalam kandang itu, namun segera membuang muka karena tak tahan melihat penyiksaan itu. Tapi dunia yang hadir, mengepungnya di sana dan membuatnya tersadar. Dusun itu rumpang. Sekitar seratus rumah petak tiga kali enam meter berserakan di daerah itu. Namun lebih dari sepertiganya telah ditinggalkan. "Orang-orang pergi" kata Anson yang buta matanya sebelah, sebab harga karet jatuh hingga begitu murahdan kebun kami terus menerus diserang cendawan putih ataupun merah. Orang-orang tak bisa lagi menggantingkan diri dari hasil panen karet. Kami berdua serta ibu yang masih menderas getah, sedang ayah dan abang sulung pergi menjadi buruh. Tak ada uang untuk mengobati Upi." (Saman, 2006: 72).

Relasi antara Saman dan Upi terjadi karena rasa cinta kasih antar sesama manusia. Cinta yang dimaksud adalah panggilan hati Wisanggeni untuk menerima Upi, keluarganya dan para petani karet di Sei Kumbang itu sebagai panggilan kewajiban. Wisanggeni merasa terharu dan tidak tahan melihat penderitaan kelaurga Mak Argani dan penyiksaan terhadap Upi, gadis cacat mental. Upi terpaksa dipasung kakinya dan tinggal di gubuk yang berukuran 2 x 1 meter. Pemasungan itu dilakukan bukan karena tidak ada kasih sayang tetapi karena ketidakberdayaan untuk mengobati Upi.

Wisanggeni juga memiliki relasi yang baik dengan Angson. Hal ini dapat dilihat pada kutipan 2 berikut.

Kutipan 2

"Ketika ia tiba suatu hari, ada keributan kecil di desa Sei Kumbang. Anson dan dua pemuda lain duduk di bale-bale dengan muka berdarah. Beberapa ibu mengompres wajah mereka yang lebam dengan rebusan daun sirih. "Ada operasi mendadak, kata orang-orang". Penjaga kebun memergoki ketiganya menjual getah pada tengkulak. Emberember dirampas dan mereka dipukuli karena dianggap mencuri lateks dari PTP X. (Saman, 2006: 73).

Hubungan Wisanggeni dengan Upi, Anson, dan para petani karet di Sei Kumbang didasari oleh cinta yang timbul dari hubungan sosial, sebagaimana yang digambarkna oleh Levinas. Hubungan cinta yang timbul dari hubungan sosial sebagai panggilan kewajiban itu dapat dilihat pada kutipan berikut ini.

\section{Kutipan 3}

"Wis mendengar Upi diperkosa, melihat rumah-rumah asap dan rumah penduduk dibakar, istri Anson diperkosa 
para penduduk dipaksa untuk menandatangani kertas kosong, dan pohon karet dibolduzer" (Saman, 2006: 91).

Berdasarkan kutipan 3 diatas dapat dijelaskan bahwa peristiwa itu membuat Wis gelisah. Wis telah melihat kesengsaraan di balik kotakota maju, tetapi belum pernah ia saksikan keterbelakangan seperti di desa Sei Kumbang itu. Seorang gadis teraniaya bukan karena ekses keserakahan melainkan karena orang-orang tidak mampu mencapai kemodernan. Kemiskinan dan kesewenang-wenangan terjadi di sekitanrya. Wisanggeni melihat sebagai penindasan kepada ketidakberdayaan.

Hubungan tersebut oleh Marcel disebut dengan pertemuan. Pertemuan itu didasari oleh cinta yang timbul dari suatu panggilan kewajiban sebagaimana yang dinyatakan oleh Levinas. Bentuk pertemuan tersebut dapat diketahui dalam kutipan berikut ini.

\section{KESIMPULAN}

Relasi antara Sihar dan Laila bukan merupakan pertemuan yang sebenarnya sebab pertemuan itu lebih didasari oleh dorongan biologis dan psikologis, bukan dorongan untuk saling membuka hati dengan jujur dan saling menerima. Oleh karnea itu, pertemuan itu tidak menjadi relasi dalam kata "Kita".

$$
\text { Relasi antara Saman dan }
$$

Yasmin merupakan relasi yang didasari oleh cinta, sehinga hubungan itu berada dalam relasi "Kita" atau pertemuan yang sebenarnya. Cinta yang mendasari hubungan itu timbul oleh adanya kerendahan hati dari Yasmin dan kesediaan hati Saman untuk saling membuka hati dengan jujur, saling menerima dan saling mengakui masing-masing sebagai subjek, sehingga masing-masing bersedia untuk saling mendengarkan pikiranpikiran, perasaan dan cita-cita mereka dalam kebesramaan.

$$
\text { Relasi antara Wisanggeni }
$$
(Saman) dengan Upi, Anson dan para petani karet merupakan hubungan etis, hubungan kewajiban. Hubungan itu dimulai dari hubungan sosial yang didasari oleh hubungan keadilan dan kebaikan.

\section{SARAN}

Novel Saman Karya Ayu Utami dapat digunakan untuk bahan pengkajian karya sastra dilihat dari sudut pandang relasi dan motivasi antar tokoh. Berkaitan dengan 
alternatif sebagai bahan pengajaran apresiasi disarankan agar diajarkan pada Sekolah Tingkat Atas atau perguruan tinggi. Jika guru ingin mengajarkan di tingkat dasar dan menengah, sebaliknya guru memberikan terlebih dahulu gambaran citra relasi antar manusia yang diidealkan dalam kehidupan manusia, sehingga siswa dapat menganalisis dan mengapresiasi secara kritis-kreatif.

\section{DAFTAR RUJUKAN}

Endraswara. Suwardi. 2008 Metodologi Penelitian Sastra:

Epistemologi, Model, Teori, dan Aplikasi. Yogyakarta: Media Pressindo.

Faruk. 2012. Pengantar Sosiologi Sastra: Dari Strukturalisme Genetik sampai Postmodernisme. Yogyakarta: Pustaka pelajar.

Nurgiyantoro, Burhan. 2008. Teori Pengkajian Fiksi. Yogyakarta: Gajah Mada University Press.

Utami, Ayu. 2006. Saman. Jakarta: KPG (Kepustakaan Populer Gramedia). 